\title{
Synergic effects between ocellatin-F1 and bufotenine on the inhibition of BHK-21 cellular infection by the rabies virus
}

Rene dos Santos Cunha Neto ${ }^{1,2}$, Hugo Vigerelli ${ }^{1}$, Carlos Jared ${ }^{3}$, Marta Maria Antoniazzi ${ }^{3}$, Luciana Botelho Chaves ${ }^{2}$, Andréa de Cássia Rodrigues da Silva ${ }^{2}$, Robson Lopes de Melo ${ }^{4}$, Juliana Mozer Sciani ${ }^{1}$ and Daniel C. Pimenta ${ }^{1 *}$ (D)

\begin{abstract}
Background: Rabies is an incurable neglected zoonosis with worldwide distribution characterized as a lethal progressive acute encephalitis caused by a lyssavirus. Animal venoms and secretions have long been studied as new bioactive molecular sources, presenting a wide spectrum of biological effects, including new antiviral agents. Bufotenine, for instance, is an alkaloid isolated from the skin secretion of the anuran Rhinella jimi that inhibits cellular penetration by the rabies virus. Antimicrobial peptides, such as ocellatin-P1 and ocellatin-F1, are present in the skin secretion of anurans from the genus Leptodactylus and provide chemical defense against predators and microorganisms.
\end{abstract}

Methods: Skin secretion from captive Leptodactylus labyrinthicus was collected by mechanical stimulation, analyzed by liquid chromatography and mass spectrometry, and assayed for antiviral and cytotoxic activities. Synthetic peptides were obtained using solid phase peptide synthesis, purified by liquid chromatography and structurally characterized by mass spectrometry, and assayed in the same models. Cytotoxicity assays based on changes in cellular morphology were performed using baby hamster kidney (BHK-21) cells. Fixed Rabies virus (Pasteur Virus - PV) strain was used for virological assays based on rapid fluorescent focus inhibition test.

Results: Herein, we describe a synergic effect between ocellatin-F1 and bufotenine. This synergism was observed when screening the L. labyrinthicus skin secretion for antiviral activities. The active fraction major component was the antimicrobial peptide ocellatin-F1. Nevertheless, when the pure synthetic peptide was assayed, little antiviral activity was detectable. In-depth analyses of the active fraction revealed the presence of residual alkaloids together with ocellatin-F1. By adding sub-effective doses (e.g. $<I_{50}$ ) of pure bufotenine to synthetic ocellatin-F1, the antiviral effect was regained. Moreover, a tetrapetide derived from ocellatin-F1, based on alignment with the virus's glycoprotein region inferred as a possible cell ligand, was able to maintain the synergic antiviral activity displayed by the full peptide.

Conclusions: This novel antiviral synergic effect between a peptide and an alkaloid may present an innovative lead for the study of new antiviral drugs.

Keywords: Rabies virus, Ocellatin-F1, Bufotenine, Toxin, Leptodactylus

\footnotetext{
* Correspondence: dcpimenta@butantan.gov.br

'Butantan Institute, Laboratory of Biochemistry and Biophysics, Av. Vital Brazil,

1500, São Paulo, SP 05503-900, Brazil

Full list of author information is available at the end of the article
} 


\section{Background}

Rabies is an incurable zoonosis with worldwide distribution characterized as a lethal progressive acute encephalitis responsible for more than 55 thousand deaths per year, mostly in Asia and Africa [1]. In Brazil, according to the Ministry of Health, there have been 780 notified human rabies cases from 1986 to 2015 [2]. It is caused by a neurotropic enveloped virus, the Rabies virus, which has a single non-segmented negative strand RNA genome that encodes five proteins: nucleoprotein, RNA-dependent RNA polymerase, phosphoprotein, matrix protein and glycoprotein [3].

Glycoprotein is a membrane protein that forms trimers on the viral surface and it is the major antigen responsible for inducing the production of virus-neutralizing and protective antibodies [4]. It is also the protein that most contributes to the viral pathogenicity, by binding to specific host cell receptors, promoting the virus's entry into the cells [5]. The first described target for glycoprotein binding was a nicotinic acetylcholine receptor (nAChR) [6]. Other molecules, such as the neural cell adhesion molecule (NCAM) and the low-affinity neurotrophin receptor (p75NTR), are also considered mediators of the virus's entrance into the host cells $[7,8]$.

Different organisms have been used as sources of biologically active molecules [9]. Amphibian skin extract and secretions contain a great diversity of bioactive compounds that provide chemical protection against predators and microorganisms [10]. Several bioactive molecules, such as alkaloids, steroids and peptides, have been isolated from the anurans skin secretion [11-13]. The genus Leptodactylus, which includes 75 species spread across southern North America, South America and the West Indies, has already been prospected for such bioactive molecules, including by our group [14, 15]. The alkaloid leptodactyline, for example, possesses muscle relaxant action and neuromuscular blocking effects [16]. Ocellatin-P1 (formerly known as pentadactylin, according to the nomenclature proposed by Conlon [17]), an antimicrobial peptide isolated from the skin secretion of Leptodactylus pentadactylus, is active against several gram-negative and gram-positive bacteria; whereas ocellatin-F1 (previously known as fallaxin), obtained from the giant ditch frog Leptodactylus fallax skin secretion, presents antimicrobial activity against gram-negative bacteria [17-19].

Taking into account that the amphibian skin secretions are rich sources of bioactive molecules - including antiviral molecules - and that the biochemical characterization of molecules isolated from Leptodactylus labyrinthicus is still incipient, the aim of this study was to screen the skin secretion of L. labyrinthicus to search for bioactive molecules that actively inhibit infection by the rabies virus in BHK-21 cell line.

\section{Methods}

\section{Reagents}

All reagents employed in this work were of analytical grade and were purchased from Sigma Aldrich Co. (USA), unless otherwise stated. Bufotenine was purified from Anadenanthera colubrina seeds, as previously described [11].

\section{Collection of specimens and extraction of skin secretions}

The collection and housing of L. labyrinthicus were performed under license number 15964-1 from the Brazilian Institute of Environment and Renewable Natural Resources (IBAMA). Three adult male specimens were collected in Araraquara (SP, Brazil) and maintained in captivity at the Laboratory of Cell Biology, Butantan Institute (SP, Brazil). The skin secretions were mechanically collected by submerging and gently compressing the specimens in deionized water. The aqueous solutions obtained were lyophilized and stored at $-20{ }^{\circ} \mathrm{C}$.

\section{Samples preparation}

Skin secretions were filtered in $10 \mathrm{kDa}$ cut-off membranes (Amicon Ultra-4, Millipore). Filtered contents were used in the subsequent steps.

\section{Reversed-phase liquid chromatography}

Skin secretion solutions were analyzed by reversedphase high-performance liquid chromatography (RPHPLC) using a binary HPLC system (20A Prominence, Shimadzu Co., Japan). Aliquots of the secretions were loaded in a C18 monolithic column (Phenomenex, 100 $\mathrm{mm} \times 4.6 \mathrm{~mm})$, in a two solvent system: $\left(\mathrm{A}_{1}\right)$ trifluoroacetic acid (TFA)/water $(1: 1,000)$ and $\left(B_{1}\right)$ TFA/acetonitrile (ACN)/water (1:900:100). The column was eluted at a constant flow rate of $2 \mathrm{~mL} \cdot \mathrm{min}^{-1}$ with a 0 to $100 \%$ gradient of solvent $\mathrm{B}_{1}$ over $13 \mathrm{~min}$. The eluates were monitored by a Shimadzu SPD-M20A detector at 214 $\mathrm{nm}$. After skin secretion profiles, fractions were manually collected and dried for subsequent assays.

\section{Mass spectrometry \\ Liquid chromatography-mass spectrometry (LC-MS)}

LC-MS analyses were performed using an electrosprayion trap-time of flight (ESI-IT-TOF) (Shymadzu Co., Japan) mass spectrometer equipped with binary ultra-fast liquid chromatography system (UFLC) (20A Prominence, Shimadzu Co., Japan). Aliquots of each material were dried, resuspended in $0.1 \%$ formic acid (FA) and loaded in a C18 column (Shimadzu-pack XR-ODS, $2.2 \mu \mathrm{m} ; 100$ $\mathrm{mm} \times 3 \mathrm{~mm})$ in a binary solvent system: $\left(\mathrm{A}_{2}\right)$ FA/water $(1: 1,000)$ and $\left(\mathrm{B}_{2}\right) \mathrm{FA} / \mathrm{ACN} /$ water $(1: 900: 100)$. The column was eluted at a constant flow rate of $0.2 \mathrm{~mL} \cdot \mathrm{min}^{-1}$ with a 0 to $100 \%$ gradient of solvent $B_{2}$ over $20 \mathrm{~min}$. The eluates were monitored by a Shimadzu SPD-M20A PDA detector 
before introduction into the mass spectrometer, in which the spray voltage was kept at $4.5 \mathrm{kV}$, the capillary voltage at $1.76 \mathrm{kV}$, and temperature at $200{ }^{\circ} \mathrm{C}$. MS spectra were acquired under positive ionization mode and collected in the $80-2,000 \mathrm{~m} / z$ range. Instrument control, data acquisition, and data processing were performed with LabSolutions (LCMS solution 3.60.361 version, Shimadzu Co., Japan).

\section{Direct infusion mass spectrometry}

MS analyses were performed in an ESI-IT-TOF as described above. Previously dried skin secretion fractions were resuspended in $0.5 \% \mathrm{FA}$, for positive mode electrospray ionization (ESI+), and manually injected in a Rheodyne injector at a flow rate of $50 \mu \mathrm{L} \cdot \mathrm{min}^{-1}$, in $50 \%$ FA/ACN/water (5:900:100). Instrument control, data acquisition, and data processing were performed by the software LabSolutions (LCMS solution 3.60.361 version, Shimadzu Co., Japan).

\section{Peptide synthesis}

Synthetic peptides were obtained in an automated benchtop simultaneous multiple solid-phase synthesizer (PSSM 8 system from Shimadzu Co., Japan) using solid-phase peptide synthesis by the Fmoc-Procedure [20, 21]. Peptides were purified by reversed-phase chromatography (Shimadzu Co., Shim-pack Prep-ODS, $5 \mu \mathrm{m}, 20 \times 250$ $\mathrm{mm})$ semi-preparative HPLC, whereas the purity and identity of the peptides were confirmed by ESI-IT-TOF mass spectrometry and by analytical HPLC, under the same conditions described above.

\section{Cell culture and viruses}

Baby hamster kidney (BHK-21, ATCC CCL-10) cells, grown in Eagle's minimum essential medium (MEM), containing Earle's salts supplemented with 10 \% fetal bovine serum (FBS), were used for the cytotoxicity and virology assays. The fixed Rabies virus (PV) strain was used for the virology assay [22]. The assays were performed in 96-well microplates.

\section{Cytotoxicity assay}

The cytotoxic effect of different molecules was evaluated by a test based on morphological changes of BHK-21 cells.

Briefly, samples were diluted in MEM-FBS and deposited in 96-well microplates, according to the items described below. Using MEM-FBS as diluent, serial fourfold dilutions of these samples were performed in $50 \mu \mathrm{L}$ volumes. Then, $100 \mu \mathrm{L}$ of BHK- 21 cells suspension $(2.5 \times$ $10^{5}$ cells. $\mathrm{mL}^{-1}$ ) were added to each well and incubated at $37{ }^{\circ} \mathrm{C}$ for $20 \mathrm{~h}$, in a $5 \% \mathrm{CO}_{2}$ atmosphere. Following incubation, cells were observed in an optical microscope (Carl-Zeiss), using 100× magnification; formation of a confluent cell monolayer was analyzed in comparison to positive [dimethyl sulfoxide - DMSO diluted into MEM-FBS (1:5)] and negative (MEM-FBS) cytotoxicity controls.

\section{Virology assay}

The effect of different molecules, dissolved into MEMFBS, as interfering agents of rabies virus infection in BHK-21 cells, was evaluated by rapid fluorescent focus inhibition test (RFFIT) adapted for microplates [23, 24]. Samples were added to 96-well microplates, according to the description below.

Using MEM-FBS as diluent, serial fourfold dilutions of these samples were performed in $50 \mu \mathrm{L}$ volumes. PV strain suspension previously titered $\left(30 \mathrm{FFD}_{50}\right), 50 \mu \mathrm{L}$, was added to each well. Then, $100 \mu \mathrm{L}$ of BHK-21 cellular suspension $\left(2.5 \times 10^{5}\right.$ cells. $\left.\mathrm{mL}^{-1}\right)$ was added per well and microplates were incubated at $37^{\circ} \mathrm{C}$, for $20 \mathrm{~h}$, in a 5 $\% \mathrm{CO}_{2}$ atmosphere. After incubation, the medium was aspirated and microplates were cooled on ice. Cell monolayer was fixed by adding cold $80 \%$ acetone into the wells. After $15 \mathrm{~min}$, acetone was discarded by inversion and microplates were dried at $37{ }^{\circ} \mathrm{C}$. The staining step was performed by adding $40 \mu \mathrm{L}$ of antirabies immunoglobulin conjugated with fluorescein isothiocyanate produced by Instituto Pasteur (SP, Brazil) [25], previously titrated. Microplates were incubated at $37^{\circ}$ $\mathrm{C}$, for $1 \mathrm{~h}$, in a $5 \% \mathrm{CO}_{2}$ atmosphere. After this, microplates were washed by submerging them in three changes of phosphate buffered saline (PBS) and then in three changes of distilled water. Microplates were inverted and shaken for water removal. Finally, $50 \mu \mathrm{L}$ of glycerin/ PBS solution (1:10) was added to each well. BHK-21 cells + MEM-FBS and PV + BHK-21 cells + MEM-FBS were used, respectively, as cell viability and virus infectivity controls. Cells were observed in an inverted fluorescence microscope (Leica DMIL), using 200× magnification, and 18 fields per well were analyzed, and fields containing fluorescent foci (infected cells) were counted.

\section{Statistical analyses}

Samples were assayed in duplicates in both assays. Results are presented as mean \pm standard error of mean. Statistical evaluation of data was carried out by one-way analysis of variance (ANOVA) followed by Tukey post-test (virology assay). Differences were considered statistically significant when $p<0.05$.

\section{Results}

Initial RP-HPLC analyses of the crude L. labyrinthicus skin secretions (Fig. 1, inset) suggested similar profiles among the three specimens, allowing the pooling of the individual secretions for subsequent fractionation (Fig. 1). Fractions were manually collected, lyophilized and tested for cytotoxic and antiviral activity (data not shown). 


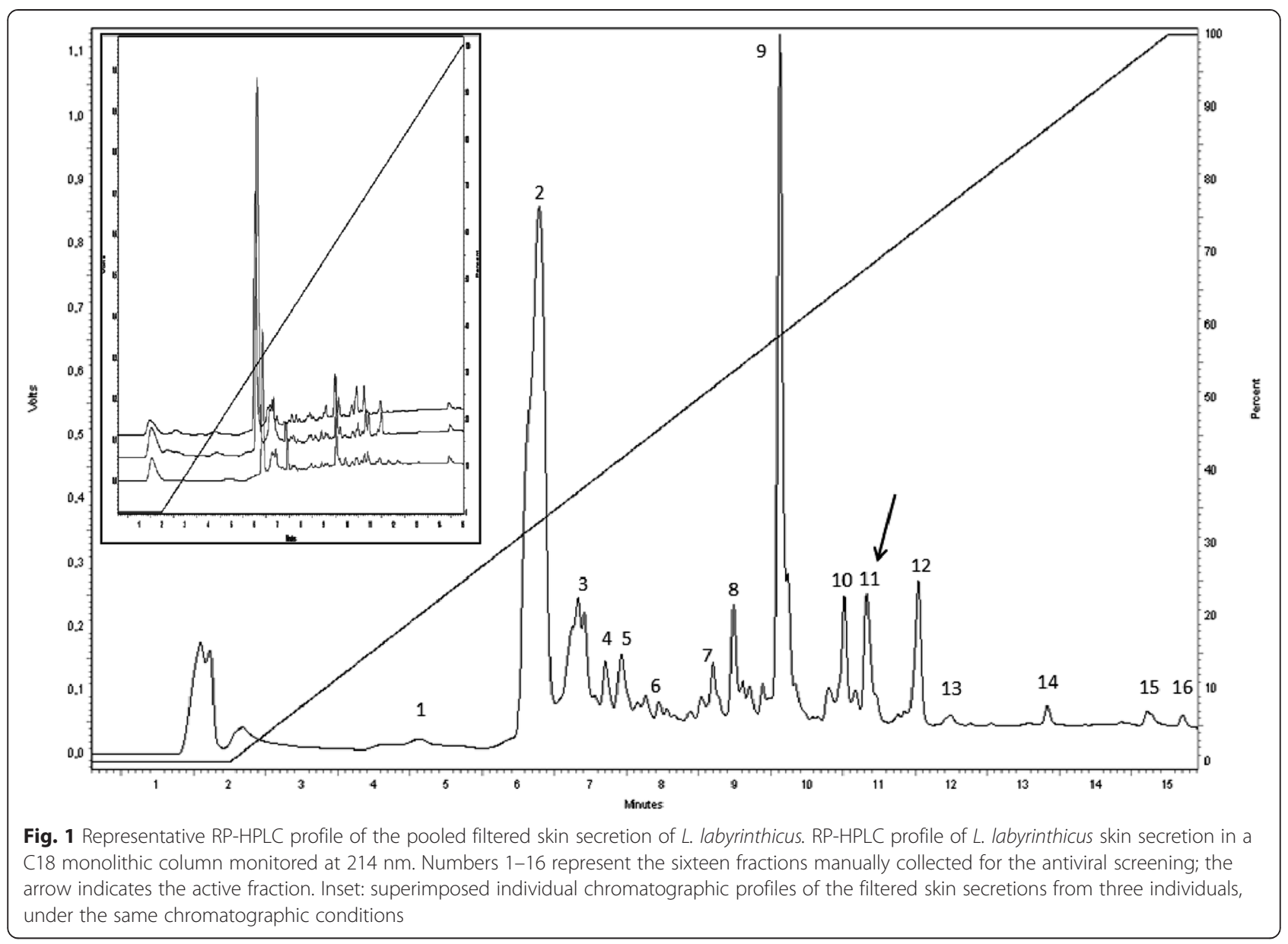

Under our experimental conditions only one fraction (F11) was active and is indicated by the arrow, in Fig. 1.

Mass spectrometric analyses of F11 (Additional file 1) showed the presence of two peptides: $(2547.98 \pm 0.16 \mathrm{Da}$ and $2192.80 \pm 0.16 \mathrm{Da}$ ), as well as other minor lowmolecular-mass compounds. Both peptides were selected for $\mathrm{MS}^{2}$ CID fragmentation (Additional file 2, $\mathrm{MS}^{2}$ of $\mathrm{m} / \mathrm{z}=850.16$ ) and were de novo sequenced with the aid of the software Peaks Studio v7 (Bionformatics Solutions Inc., Canada), being identified as ocellatin-F1 (GVVDILKGAAKDIAGHLASKVMNKL; Fig. 2a) and Des-Lys ${ }^{24}$-Leu $^{25}$-ocellatin-F1 (GVVDILKGAAKDIAGHLASKVMN; Fig. 2b). Ocellatin-F1, termed OF1, was then synthesized by the Fmoc procedure and the $\mathrm{MS}^{2}$ CID spectrum of the triply charged peptide is presented in Additional file 2, for the sake of comparison with the natural peptide fragmentation pattern of the corresponding ion.

The peptide sequence of OF1 was then compared with the rabies virus glycoprotein region that was supposed to mediate virus internalization (Table 1) and similarity could be observed (boxed region) between the tetrapeptide associated with the nAChR recognition, $\mathrm{N}^{194}-\mathrm{S}-\mathrm{R}-\mathrm{G}^{197}$, and $\mathrm{A}^{18}-\mathrm{S}-\mathrm{K}-\mathrm{V}^{21}$ OF1 internal peptide. Both tetrapeptides were synthesized by the Fmoc strategy and assayed for antiviral activity under the same experimental conditions employed for the screening of the antiviral activity (Additional file 3). OF1 tetrapeptide was termed OF1TP and the rabies virus glycoprotein G tetrapeptide was termed RVGTP. At the tested concentrations, F11, synthetic OF1, OF1TP and RVGTP did not present cytotoxic activity (Additional file 4).

Figure 3 displays the direct immunofluorescence assays (DIF) used for the determination of the antiviral activity, assessed by means of identification and counting of viral particles inside the cells, revealed by the conjugated fluorescent antibody. These data were then converted into percentage of viral infection inhibition and are presented in Fig. 4 . The F11 $\left(1.0 \mathrm{mg} \cdot \mathrm{mL}^{-1}\right)$ was able to reduce by $6 \%$ the viral infection (Figs. 3a and 4). However, when synthetic $1.0 \mathrm{mg} \cdot \mathrm{mL}^{-1}$ OF1 was assayed under the same conditions, it caused a diminished inhibitory effect: $3 \%$ inhibition of infection (Figs. 3b and 4). OF1TP was able to inhibit $6 \%$ of the viral infection, but only when assayed at $6.0 \mathrm{mg} \cdot \mathrm{mL}^{-1}$ (Figs. 3c and 4). On the other hand, RVGTP did not inhibit the viral infection (data not shown). 


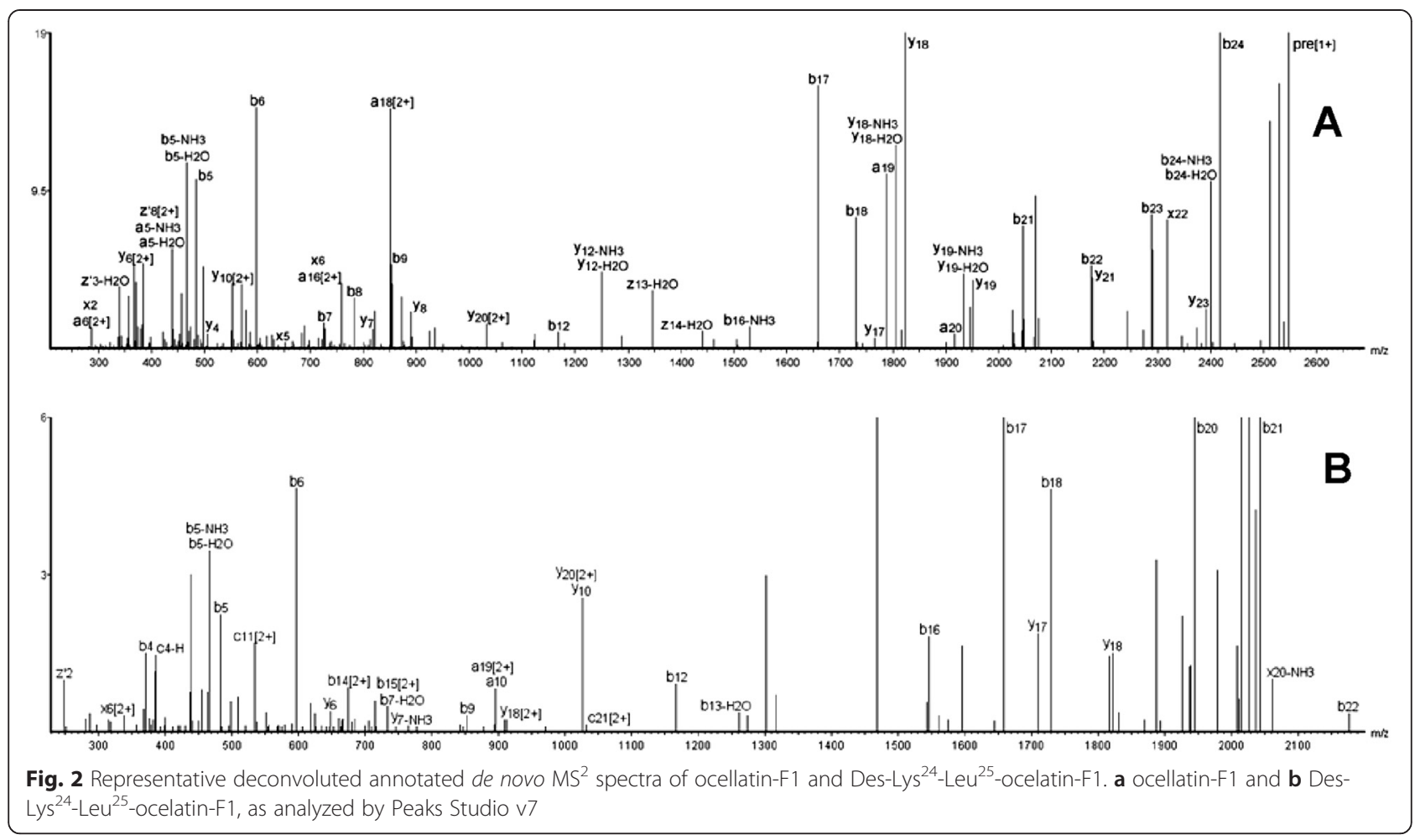

In order to understand the reduced effect of OF1 in relation to F11, its mass spectrum (Additional file 1) was re-analyzed, thereby revealing the presence of lowmolecular-mass compounds, particularly $\mathrm{m} / \mathrm{z}=219.13$, identified as N'N,'N'-trimethyl-5-hydroxytryptamine (5HTQ), based on the high accuracy of mass determination, which allowed formula prediction, and the presence of the characteristic spontaneous fragment $\mathrm{m} / \mathrm{z}=160.06 .5$-HTQ is an alkaloid commonly found in amphibian skin secretions, often together with the antiviral alkaloid bufotenine. In order to investigate the possible synergic effect between alkaloids and OF1 on the inhibition of the RABV infection, sub-effective doses of pure plant-derived bufotenine were assayed under the same conditions (Fig. 3d) and in association with F11 (Fig. 3e), synthetic OF1 (Fig. 3f), OF1TP (Fig. 3g) and RVGTP (data not shown).

The $0.8 \mathrm{mg} \cdot \mathrm{mL}^{-1}$ bufotenine dose (corresponding to half of the $\mathrm{IC}_{50}$ dose for the antiviral effect) was considered subeffective, e.g., only capable of inducing mild effects and not $100 \%$ inhibition [11]. This dose was able to cause a $22 \%$ reduction in the viral infection (Fig. 4) and was not cytotoxic for BHK-21 cells (Additional file 4). On the other hand, when $0.8 \mathrm{mg} \cdot \mathrm{mL}^{-1}$ bufotenine was added to $1 \mathrm{mg} \cdot \mathrm{mL}^{-1} \mathrm{~F} 11$, $1 \mathrm{mg} \cdot \mathrm{mL}^{-1}$ synthetic OF1 or $6 \mathrm{mg} \cdot \mathrm{mL}^{-1}$ OF1TP, $100 \%$ virus infection inhibition could be observed, indicating a synergic effect between the peptide and the alkaloid (Fig. 4), which is statistically different $(p<0.001)$ from the infection inhibitory effect of the molecules tested individually.

Table 1 Sequence alignment between ocellatin-F1 and the RABV glicoprotein G region associated with cell penetration

\begin{tabular}{|c|c|}
\hline Peptide/Protein & Sequence \\
\hline Ocellatin-F1 & ${ }^{1} G$ V V D I L K G A A K D I A G H L A K VMNKL \\
\hline RABV glicoprotein ${ }^{a}$ & ${ }^{177}$ T I M P ENRPGT P D I T N SRGRAS \\
\hline Consensus & * : . \\
\hline
\end{tabular}



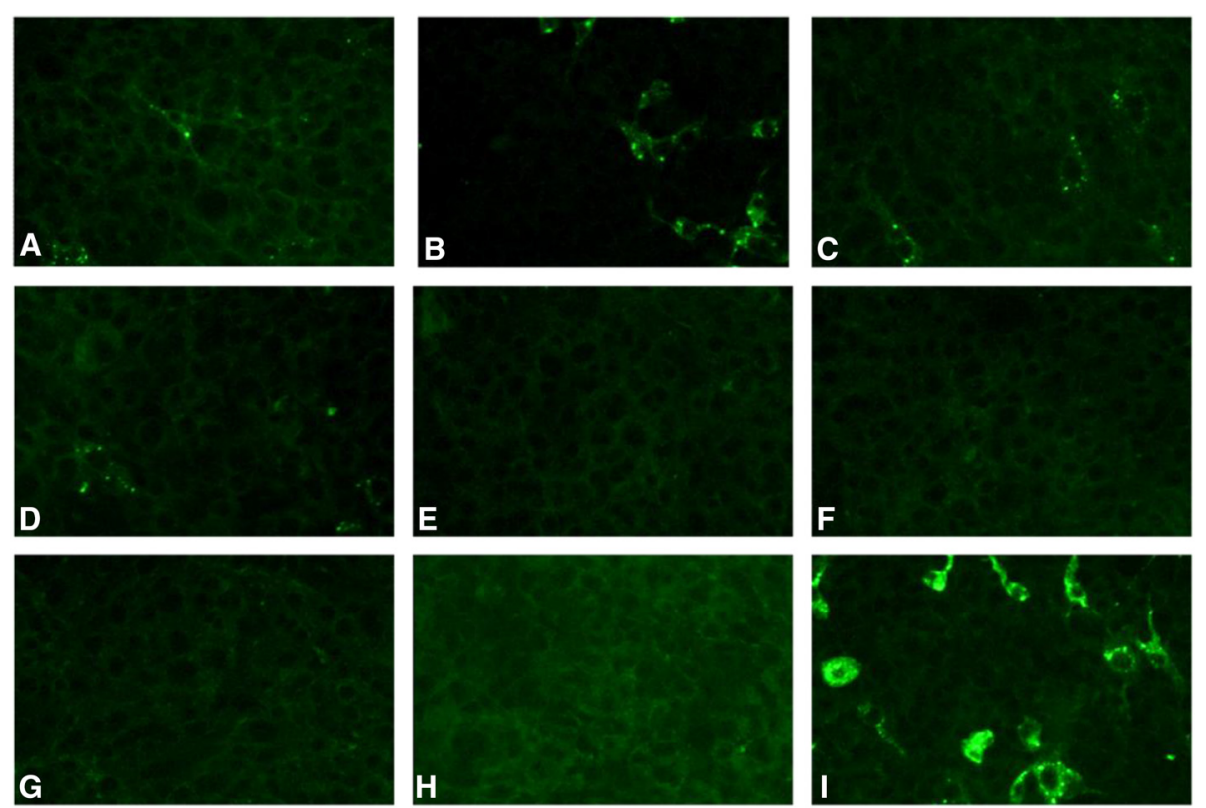

Fig. 3 Direct immunofluorescence (DIF) of BHK-21 cell monolayer after treatment with RABV and different molecules. a F11 (1.0 mg.mL $\left.{ }^{-1}\right)$; b synthetic OF1 (1.0 mg.mL $\left.{ }^{-1}\right)$; c OF1TP $\left(6.0 \mathrm{mg} \cdot \mathrm{mL}^{-1}\right)$; d bufotenine $\left(0.8 \mathrm{mg} \cdot \mathrm{mL}^{-1}\right)$; e bufotenine $\left(0.8 \mathrm{mg} \cdot \mathrm{mL}^{-1}\right)$ and F11 $\left(1.0 \mathrm{mg} \cdot \mathrm{mL}^{-1}\right)$; f bufotenine $\left(0.8 \mathrm{mg} \cdot \mathrm{mL}^{-1}\right)$ and synthetic OF1 $\left(1.0 \mathrm{mg} \cdot \mathrm{mL}^{-1}\right) ; \mathbf{g}$ bufotenine $\left(0.8 \mathrm{mg} \cdot \mathrm{mL}^{-1}\right)$ and OF1TP $\left(6.0 \mathrm{mg}^{\mathrm{mL}}{ }^{-1}\right) ; \mathbf{h}$ negative control (MEM-FBS only) and $\mathbf{i}$ positive control (PV only). Magnification 200x

\section{Discussion}

In this work, we report not only the isolation and biochemical characterization of ocellatin-F1 (OF1) and DesLys $^{24}$-Leu ${ }^{25}$-OF1 from the skin secretion of $L$. labyrinthicus, but also that OF1 possesses mild antiviral effect on the inhibition of rabies virus infection in BHK-21 cells. This effect can reach $100 \%$ when in synergism with bufotenine, an already know antiviral alkaloid isolated from the skin secretion of Rhinella jimi [11].

In this study, OF1 was isolated through a biological driven-assay, monitoring anti-rabies activity. The active fraction - which contained OF1, Des-Lys ${ }^{24}-$ Leu $^{25}$-OF1 and low-molecular-mass molecules - was able to decrease the PV rabies virus strain infection in BHK-21 cells.

OF1 was first isolated from the skin secretion of $L$. fallax, but has also been found in other species from the genus Leptodactylus, including $L$. pentadactylus and $L$. labyrinthicus $[18,19,26]$. It is a 25 -amino-acid residue peptide able to inhibit the growth of gram-negative bacteria (Escherichia coli, Pseudomonas aeruginosa, Enterobacter cloacae, Klebsiella pneumoniae), but inactive against Staphylococcus aureus (gram-positive bacterium) and the yeast Candida albicans [19]. Rollins-Smith et al. [19] also mention the structural similarity between OF1 and ranatuerin-2, an antimicrobial peptide from Rana catesbeiana, which presents antimicrobial activity towards S. aureus [27]. Remarkably, antiviral activity of ranatuerin- 2 has already been reported against the frog virus 3 (FV3) - capable of causing Amphibia mass mortality - and the channel catfish virus (CCV) - which causes significant economic loss in channel catfish farms [28]. Based on these findings, OF1 was elected as the candidate for the following antiviral tests, performed with the synthetic molecule. Nevertheless, pure synthetic OF1 was not as effective as F11 (Fig. 4).

Two possibilities may account for the reduced activity of OF1: ranatuerin has a disulfide bond at the C-terminus (between $\mathrm{Cys}^{23}$ and $\mathrm{Cys}^{28}$ ), whereas OF1 is a linear peptide; and the identity between OF1 and ranatuerin encompasses the central part of the peptide ( $\left.{ }^{6} \mathrm{LKGAAKDI}{ }^{13} \mathrm{AGH}^{16} \mathrm{~L}^{17}\right)$, with $\mathrm{Ile}^{13}$ and $\mathrm{His}^{16}$ being not identical but conserved. Moreover, this identity ceases before the ring region in ranatuerin and at the residue $\left(\mathrm{Leu}^{17}\right)$ immediately prior to the tetrapeptide considered similar to the rabies virus glycoprotein region associated with the viral cell penetration (Table 1). Therefore, the determinants of specificity for the antiviral activity appear to be located at the C-terminal of these peptides and are distinct.

To test this hypothesis, a fragment of the C-terminal region of OF1 (considered similar to the rabies virus glycoprotein) was synthesized and assessed for antiviral activity. Although the dose was higher $\left(6 \mathrm{mg} \cdot \mathrm{mL}^{-1}\right.$ versus 1 $\mathrm{mg} \cdot \mathrm{mL}^{-1}$ for OF1), OF1TP was able to retain its antiviral activity, corroborating the hypothesis that the antiviral activity of these antimicrobial peptides is located at their Ctermini. 


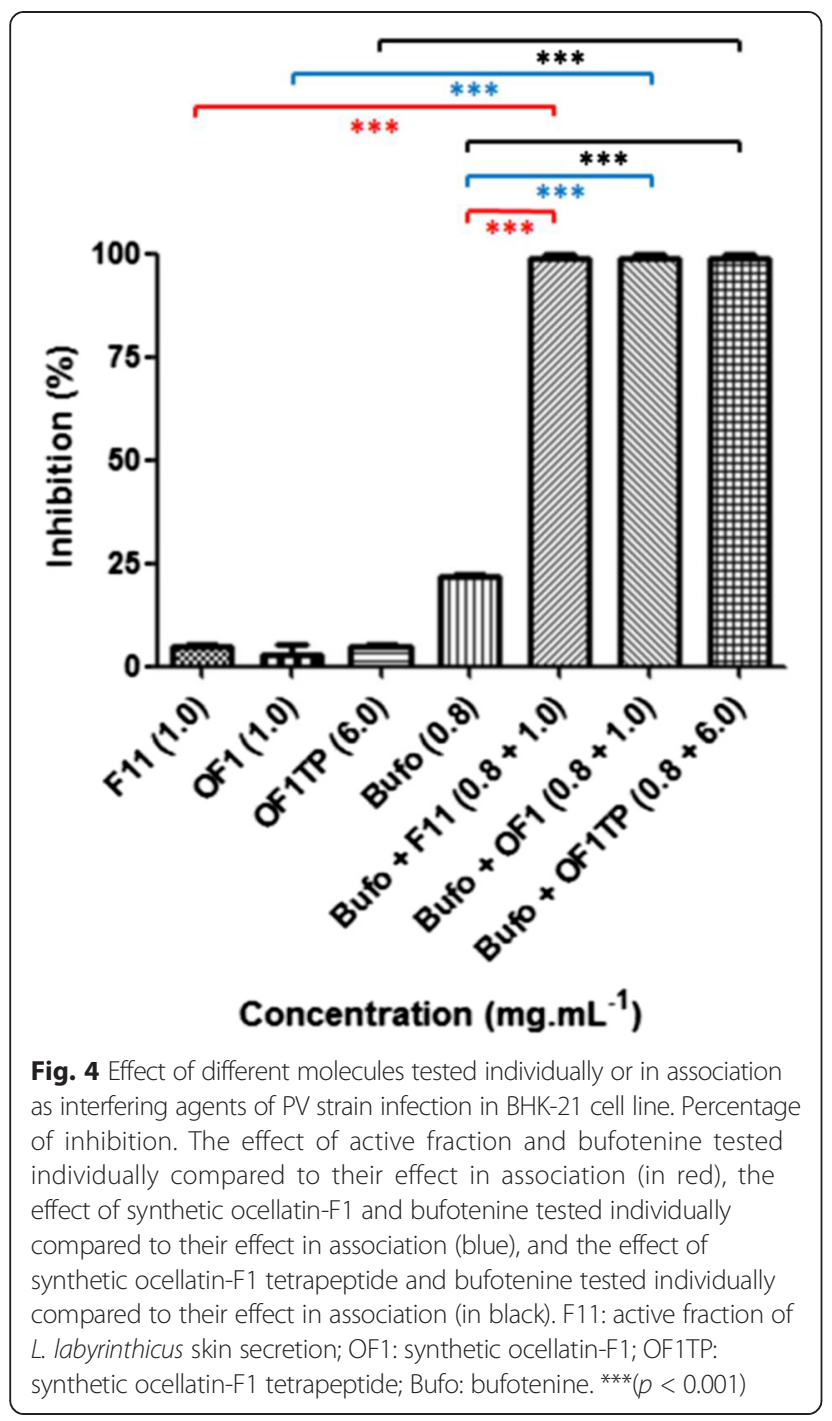

In-depth analyses of the mass spectra of the active fraction from L. labyrinthicus skin secretion (F11, Additional file 1) showed that, besides Des-Lys ${ }^{24}$-Leu ${ }^{25}$-OF1 that also contains the OF1TP sequence, low-molecular-mass molecules, particularly 5-HTQ, were also present. Our group has recently described the antiviral effect of bufotenine, structurally a closely related 5-HTQ alkaloid. Bufotenine is an alkaloid with noxious properties which works as a defense mechanism against predators and is able to inhibit $100 \%$ of rabies infection in BHK-21 cells, at $3.9 \mathrm{mg} \cdot \mathrm{mL}^{-1}[10,11,29]$.

Based on these pieces of information, a possible synergic effect between bufotenine and OF1 was assayed (Fig. 3e, f and g and Fig. 4). The level $0.8 \mathrm{mg} \cdot \mathrm{mL}^{-1}$, corresponding to half of the $\mathrm{IC}_{50}$, was chosen, for according to Vigerelli et al. [11] this dose would cause virus inhibition of about $20 \%$ and neglected cytotoxic effects.

Antiviral synergic effects have already been attributed to amphibian antimicrobial peptides: Chinchar et al. [30] describe a combined effect between magainin II and
ranatuerin-2P. However, these authors are unsure whether this would be a synergic effect or a simple additive effect, for they were able to obtain the same level of innactivation by simply doubling the peptide dose. Rollings-Smith et al. [31], on the other hand, were able to describe a true synergic effect between magainin II and PGLa, which present individual MICs of about $100 \mu \mathrm{M}$ for Batrachochytrium dendrobatidis; but, when added together (1:1) to this fungus, their combined MIC drops to $12.5 \mu \mathrm{M}$ (e.g., $6.25 \mu \mathrm{M}$ each). Those authors use the argument that antimicrobial peptides are naturally produced and secreted into the skin as a mixture; therefore, synergism should occur. Based on this same principle, the synergism between OF1 and bufotenine could also be expected and, from the amphibian perspective, desirable.

\section{Conclusions}

Our study shows the synergic effect of OF1 and bufotenine against the PV strain of the rabies virus. This is, to the best of these authors' knowledge, the first description of a synergic antiviral effect between a peptide and an alkaloid. Moreover, the peptide and the alkaloid are not acting on the virus; rather, their effect (individual or synergic) is on the viral penetration into the cell. Further investigations are being conducted in order to evaluate the action mechanism of the antiviral effect, as well as the possible in vivo protective effects of this molecular association.

\section{Ethics committee approval}

The collection and housing of L. labyrinthicus were performed under license number 15964-1 from the Brazilian Institute of Environment and Renewable Natural Resources (IBAMA).

\section{Additional files}

Additional file 1: Mass spectrometry profile of the active fraction (F11) from L. labyrinthicus skin secretion. Left black arrows indicate the charge states of the 2547.99 Da molecule and right white arrows indicate the charge states of the 2192.81 Da peptide. (PDF 23 kb)

Additional file 2: CID MS2 fragmentation spectra of (A) $\mathrm{m} / \mathrm{z}=850.16[\mathrm{M}+3 \mathrm{H}+]^{3+}$ present in $\mathrm{F} 11$ and $(\mathrm{B})$ the triply charged precursor of synthetic ocellatin-F1 (OF1) $(\mathrm{m} / \mathbf{z}=\mathbf{8 5 0 . 2 5})$. The most evident peaks are annotated according to the fragmentation pattern. (PDF $34 \mathrm{~kb}$ )

Additional file 3: Figure showing direct immunofluorescence (DIF) of BHK-21 cell monolayer after treatment with RABV and: (A) 4 $\mathrm{mg} \cdot \mathrm{mL}^{-1}$ synthetic ocellatin-F1 tetrapeptide (OF1TP); (B) $4 \mathrm{mg} \cdot \mathrm{mL}^{-1}$ synthetic rabies virus glycoprotein $\mathrm{G}$ tetrapeptide (RVGTP); (C) negative control (MEM-FBS only) and (D) positive control (PV only). Magnification $200 \times$. (PDF $35 \mathrm{~kb}$ )

Additional file 4: Evaluation of cytotoxicity of different molecules in BHK-21 cell line after treatment with: (A) F11 (1 mg.mL $\left.{ }^{-1}\right)$; (B) OF1 (1 $\left.\mathrm{mg} \cdot \mathrm{mL}^{-1}\right)$; (C) OF1TP (6 mg. $\left.\mathrm{mL}^{-1}\right)$; (D) RGVTP (6 mg. $\left.\mathrm{mL}^{-1}\right)$ and (E) bufotenine $\left(\mathbf{0 . 8} \mathbf{~ m g} \cdot \mathrm{mL}^{-1}\right)$. (F) Negative control (MEM-FBS only) and (G) positive control [DMSO (1:5) only]. Magnification $100 \times$. (PDF 89 kb)

\section{Competing interests}

The authors declare that there are no competing interests. 


\section{Authors' contributions}

RSCN, HV, LBC and ACRS carried out the virology experiments. CJ and MMA provided the skin secretions. RSCN and RLM synthesized the peptides. RSCN, $H V, C J, M M A, R L M, J M S$ and DCP performed the biochemical analyses. RSCN, $H V$, JMS and DCP analyzed the results and wrote the paper. DCP conceived and coordinated the study. JMS and DCP designed the experiments. All authors drafted, read and approved the final version of the manuscript.

\section{Acknowledgments}

The authors acknowledge the financial support of the State of São Paulo Research Foundation - FAPESP (project n. 2012/11280-1, RSCN), National Council for Scientific and Technological Development - CNPq (project n. 306066/2011-4, DCP), CAPES (public notice 63, HV), FINEP (cooperation agreement FINEP n. 01.09.0278.00). DCP, CJ and MMA are CNPq research fellows.

\section{Author details}

'Butantan Institute, Laboratory of Biochemistry and Biophysics, Av. Vital Brazil, 1500, São Paulo, SP 05503-900, Brazil. ²Pasteur Institute, Laboratory of Rabies Diagnostic, Serology, Avenida Paulista, 393, São Paulo 01311-000SP, Brazil. ${ }^{3}$ Butantan Institute, Laboratory of Cell Biology, Av Vital Brasil, 1500, São Paulo 05503-900SP, Brazil. ${ }^{4}$ Butantan Institute, Special Laboratory of Toxinology, Av Vital Brasil, 1500, São Paulo 05503-900SP, Brazil.

Received: 2 June 2015 Accepted: 17 November 2015 Published online: 02 December 2015

\section{References}

1. World Health Organization. Rabies Fact Sheet No 99 http://www.who.int/ mediacentre/factsheets/fs099/en. Accessed December 2014

2. Brasil. Ministério da Saúde. Raiva: Situação Epidemiológica-Dados. Raiva Humana por espécie agressora de 1986 a 2015. http://portalsaude.saude.gov. br/images/pdf/2015/junho/08/RH-POR-ESPECIE-AGRESSORA-1986-A-2015.pdf. Accessed August 2015.

3. Rupprecht CE, Hanlon CA, Hemachudha T. Rabies re-examined. Lancet Infect Dis. 2002;2(6):327-43.

4. Ross BA, Favi CM, Vásquez VA. Glicoproteína del virus rábico: estructura, inmunogenicidad y rol en la patogenia. Rev Chil Infect. 2008;25(Supl):s14-8.

5. Finke S, Conzelmann KK. Replication strategies of rabies virus. Virus Res. 2005;111(2):120-31. doi:10.1016/j.virusres.2005.04.004.

6. Lentz TL, Burrage TG, Smith AL, Crick J, Tignor GH. Is the acetylcholine receptor a rabies virus receptor? Science. 1982;215(4529):182-4.

7. Lafon M. Rabies virus receptors. J Neurovirol. 2005;11(1):82-7. doi:10.1080/ 13550280590900427.

8. Schnell MJ, McGettigan JP, Wirblich C, Papaneri A. The cell biology of rabies virus: using stealth to reach the brain. Nat Rev Microbiol. 2010;8(1):51-61. doi:10.1038/nrmicro2260

9. Calkosinski I, Zasadowski A, Bronowicka-Szydelko A, Dzierzba K, Seweryn E, Dobrzynski $M$, et al. Amphibian skin secretions as a new source of antibiotics and biologically active substances. Postepy Hig Med Dosw. 2009; 63:537-48.

10. Duellman WE, Trueb L. Biology of amphibians. New York: McGraw-Hill; 1986.

11. Vigerelli H, Sciani JM, Jared C, Antoniazzi MM, Caporale MM, da Silva ACR, et al. Bufotenine is able to block rabies virus infection in BHK-21 cells. J Venom Anim Toxins incl Trop Dis. 2014:20(1):45. doi:10.1186/1678-9199-20-45.

12. Tempone AG, Pimenta DC, Lebrun I, Sartorelli P, Taniwaki NN, de Andrade Jr $H F$, et al. Antileishmanial and antitrypanosomal activity of bufadienolides isolated from the toad Rhinella jimi parotoid macrogland secretion. Toxicon. 2008;52(1):13-21. doi:10.1016/j.toxicon.2008.05.008.

13. Conceição K, Konno K, de Melo RL, Antoniazzi MM, Jared C, Sciani JM, et al. Isolation and characterization of a novel bradykinin potentiating peptide (BPP) from the skin secretion of Phyllomedusa hypochondrialis. Peptides. 2007;28(3):515-23. doi:10.1016/j.peptides.2006.10.002.

14. Frost DR. Amphibian Species of the World: an Online Reference. http:// research.amnh.org/vz/herpetology/amphibia/?action=references\&id=18453. Accessed January 2013.

15. Sousa JC, Berto RF, Gois EA, Fontenele-Cardi NC, Honório Jr JE, Konno K, et al. Leptoglycin: a new Glycine/Leucine-rich antimicrobial peptide isolated from the skin secretion of the South American frog Leptodactylus pentadactylus (Leptodactylidae). Toxicon. 2009;54(1):23-32. doi:10.1016/j. toxicon.2009.03.011.
16. Erspamer $V$. Isolation of leptodactyline ( $m$-hydroxyphenylethyltrimethylammonium) from extracts of Leptodactylus skin. Arch Biochem Biophys. 1959;82(2):431-8.

17. Conlon JM. A proposed nomenclature for antimicrobial peptides from frogs of the genus Leptodactylus. Peptides. 2008;29(9):1631-2. doi:10.1016/j. peptides.2008.04.016.

18. King JD, Al-Ghaferi N, Abraham B, Sonnevend A, Leprince J, Nielsen PF, et al. Pentadactylin: an antimicrobial peptide from the skin secretions of the South American bullfrog Leptodactylus pentadactylus. Comp Biochem Physiol C Toxicol Pharmacol. 2005;141(4):393-7. doi:10.1016/j.cbpc.2005.09.002.

19. Rollins-Smith LA, King JD, Nielsen PF, Sonnevend A, Conlon JM. An antimicrobial peptide from the skin secretions of the mountain chicken frog Leptodactylus fallax (Anura:Leptodactylidae). Regul Pept. 2005;124(1-3):173-8. doi:10.1016/j.regpep.2004.07.013

20. Merrifield RB. Solid phase peptide synthesis. I. The synthesis of a tetrapeptide. J Am Chem Soc. 1963;85(14):2149-54. doi:10.1021/ ja00897a025.

21. Atherton E, Sheppard RC. Solid phase peptide synthesis - a practical approach. Oxford: IRL Press; 1989.

22. Batista AM, Cruz PS, Almeida E, Costa AEB, Scheffer KC, Chaves LB, et al. Infecção de células BHK-21 cultivadas em monocamadas estacionárias por cepas de vírus PV e CVS. Bol Epidemiol Paul. 2009:6(71):4-11.

23. Smith JS, Yager PA, Baer GM. A rapid reproducible test for determining rabies neutralizing antibody. Bull World Health Organ. 1973;48(5):535-41.

24. Chaves LB, Mazutti ALC, Caporale GMM, Scheffer KC, Silva ACR. Comparision of RFFIT performed in lab-tek ${ }^{\oplus}$ and in 96-well microtitre plates, In RITA XVII. Annales of the XVII International Conference on Rabies in the Americas: 15-20 octuber; 2006; Brasília, Brazil. Brasília: Ministério da Saúde; 2006. p. 161.

25. Caporale GMM, da Silva AC R, Peixoto ZM, Chaves LB, Carrieri ML, Vassao RC. First production of fluorescent anti-ribonucleoproteins conjugate for diagnostic of rabies in Brazil. J Clin Lab Anal. 2009;23(1):7-13. doi:10.1002/ jcla.20275.

26. Liberio MS. Caracterização química e biológica da secreção cutânea do anuro Leptodactylus labyrinthicus: peptídeos antimicrobianos e anticarcinogênicos, fosfolipases e peptidases. [Master's dissertation]. Brasília: Universidade de Brasília; 2008.

27. Goraya J, Knoop FC, Conlon JM. Ranatuerins: antimicrobial peptides isolated from the skin of the American bullfrog Rana catesbeiana. Biochem Biophys Res Commun. 1998;250(3):589-92. doi:10.1006/bbrc.1998.9362.

28. Chinchar VG, Wang J, Murti G, Carey C, Rollins-Smith L. Inactivation of frog virus 3 and channel catfish virus by esculentin-2P and ranatuerin-2P, two antimicrobial peptides isolated from frog skin. Virology. 2001;288(2):351-7. doi:10.1006/viro.2001.1080.

29. Handovsky H. Ein alkaloid im gifte von Bufo vulgaris. Archiv Exp Pathol Pharmakol. 1920;86(1):138-58. doi:10.1007/bf01864237.

30. Chinchar VG, Bryan L, Silphadaung U, Noga E, Wade D, Rollins-Smith L. Inactivation of viruses infecting ectothermic animals by amphibian and piscine antimicrobial peptides. Virology. 2004;323(2):268-75. doi:10.1016/j. virol.2004.02.029.

31. Rollins-Smith LA, Doersam JK, Longcore JE, Taylor SK, Shamblin JC, Carey C, et al. Antimicrobial peptide defenses against pathogens associated with global amphibian declines. Dev Comp Immunol. 2002;26(1):63-72.

\section{Submit your next manuscript to BioMed Central and we will help you at every step:}

- We accept pre-submission inquiries

- Our selector tool helps you to find the most relevant journal

- We provide round the clock customer support

- Convenient online submission

- Thorough peer review

- Inclusion in PubMed and all major indexing services

- Maximum visibility for your research

Submit your manuscript at www.biomedcentral.com/submit 